\title{
A CASE OF TONGUE SWELLING AFTER INTRAVENOUS RECOMBINANT TISSUE PLASMINOGEN ACTIVATOR ADMINISTRATION FOR ACUTE ISCHEMIC STROKE
}

\author{
Murat ÇABALAR, Hülya ERTAŞOĞLU TOYDEMIR, Anıl ÖZKAYA, Hacı Ali ERDOĞAN, Vildan YAYLA
}

Bakirkoy Dr. Sadi Konuk Training and Research Hospital, Department of Neurology, ISTANBUL, TURKEY

\section{ABSTRACT}

A 70-year-old man was admitted to our hospital with acute stroke. He had a history of hypertension with trandolaprilverapamil 4/240 mg per day therapy. He had confusion and right-sided hemiplegia. Diffusion magnetic resonance imaging revealed an ischemic lesion on the left middle cerebral artery territory. After receiving intravenous (iv) recombinant tissue plasminogen activator ( $\mathrm{r}$-tPA) infusion, he developed tongue swelling. With standard anti anaphylactic medication tongue swelling disappeared. Termination of iv r-tPA may not be required in some tongue swelling cases. Timing of angioedema, circumstances under which iv r-tPA is administered and the severity of relevant respiratory problems may be helpful in the decision of termination or continuation of iv r-tPA administration.

Keywords: Orolingual angioedema, angiotensin-converting enzyme inhibitor, alteplase, allergy.

\section{AKUT İSKEMIK İNMEDE UYGULANAN İNTRAVENÖZ REKOMBINANT DOKU PLAZMINOJEN AKTIVATÖRÜ}

\section{SONRASI OLUŞAN DİL ŞIŞMESI OLGUSU}

\section{ÖZET}

Akut inme ile hastanemize başvuran 70 yaşında erkek hasta. Özgeçmişinde hipertansiyon öyküsü olup günde 4/240 $\mathrm{mg} /$ gün trandolapril-verapamil kullanıyordu. Konfüze ve sağ hemiplejisi vardı. Difüzyon manyetik rezonans görüntülemede sol orta serebral arter sulama alanına uyan bölgede iskemi görüldü. Hastaya intravenöz (iv) r-tPA (recombinant tissue plasminogen activator) infüzyonu verildikten sonra dilde şişme gelişti. Standart anti anaflaktik tedavi uygulanması ile dil şişmesi kayboldu. Bazı dil şişmesi olgularında iv r-tPA uygulamasının sonlandırılmasına gerek olmayabilir. $\mathrm{Bu}$ iv r-tPA uygulaması sırasında orolingual anjioödem geliştiğinde solunum probleminin şiddeti bize uygulamanın devam ettirilmesine veya sonlandırılmasına yardımcı olabilir.

Anahtar Sözcükler: Orolingual anjioödem, anjiotensin-konverting enzim inhibitörü, alteplaz, allerji.

\section{INTRODUCTION}

Intravenous (IV) recombinant tissue plasminogen activator (r-tPA) is used in the treatment of patients with acute stroke in the 3 to 4.5 hours of symptom onset (1). The most serious adverse effect is hemorrhage. In recent years, orolingual angioedema was reported in some patients who received r-tPA (2). We herein report a case who had orolingual angioedema after r-tPA administration for acute ischemic stroke and recovered after standard anti anaphylactic medication in the neurologic intensive care unit.

\section{CASE}

A 70-year-old man with the history of hypertension and coronary by-pass operation was admitted to hospital with loss of consciousness and right-sided weakness. He had been receiving acetylsalisilic acid $100 \mathrm{mg}$ and trandolaprilverapamil $4 / 240 \mathrm{mg}$ per day. Neurological examination after 1 hour of symptom onset revealed confusion and right-sided hemiplegia with Glaskow Coma Scale (GKS) of 11, National Institutes of Health Stroke Scale (NIHSS) of 18, and modified Rankin Scale (mRS) of 5.

\footnotetext{
Corresponding author: Murat Çabalar, MD. Bakirkoy Dr. Sadi Konuk Training and Research Hospital, Department of Neurology, İstanbul, Turkey. Phone: +90 $02124147130 \quad$ E-mail: mcabalar@hotmail.com

Received: $18.11 .2016 \quad$ Accepted: 31.03.2017

This article should be cited as following: Çabalar M, Ertaşoğlu Toydemir H, Özkaya A, Erdoğan H.A, Yayla V. A case of tongue swelling after intravenous recombinant tissue plasminogen activator for acute ischemic stroke. Turkish Journal of Cerebrovascular Diseases 2017 ; 23 (2): 80-82. doi:10.5505/tbdhd.2017.58070
} 
A brain diffusion magnetic resonance imaging (MRI) showed acute infarction in the left middle cerebral artery (MCA) territory. His blood pressure was 160/95 $\mathrm{mmHg}$, with a pulse of 84 beats/minute, a temperature of $37.5{ }^{\circ} \mathrm{C}$. $\mathrm{He}$ received IV r-tPA in the Neurology Intensive Care Unit approximately after 2 hours of symptom onset. A total of $72 \mathrm{mg}$ IV r-tPA with $10 \%$ of total dose as bolus was applied. While the IV r-tPA infusion was almost ending, he developed right-sided tongue swelling (hemi orolingual swelling). After completing the r-tPA infusion, both sides of the tongue were swollen (Figure I). He had shortness of breath, abdominal breathing and a decrease in oxygen saturation. Consultation with the Department of Ear Nose and Throat was performed and laryngoscopic evaluation with a flexible laryngoscope revealed asymmetrical edematous tongue and larynx prominent on the right side. He was intubated in order to decrease his respiratory distress and $250 \mathrm{mg}$ methyl prednisolone IV, $50 \mathrm{mg}$ IV ranitidine, and adrenalin $0.5 \mathrm{mg}$ inhaler were applied. His tongue swelling resolved completely within 48-72 hours (Figure II). The routine computed tomography (CT) at the 24 th hour post $r$ tPA infusion showed the wide hypodense area in the left MCA territory and hemorrhage was not observed. He was extubated on the fifth day of admission. On physical examination tongue swelling was completely resolved. Global aphasia and right-sided hemiplegia was detected on his neurological examination. He improved to a NIHSS of 15 and mRS of 5 on the discharge day. He was transferred to the Department of Physical Medicine and Rehabilitation.

\section{DISCUSSION}

The number of patients with acute stroke receiving IV r-tPA in our country is increasing (3). Hemorrhagic transformation is the most dreaded adverse effect of $r$-tPA. Another adverse effect of $r$ tPA which is becoming more common in recent years is orolingual angioedema $(2,4)$. It is estimated that orolingual angioedema occurs in approximately $1.3 \%$ to $5 \%$ of patients with stroke receiving IV r-tPA $(5,6)$. The exact mechanism of action underlying the development of orolingual angioedema has not been elucidated (7). But angioedema may develop as a result of an increase in plasmin which activates the kinin pathway and leads to the formation of the vasodilator bradykinin

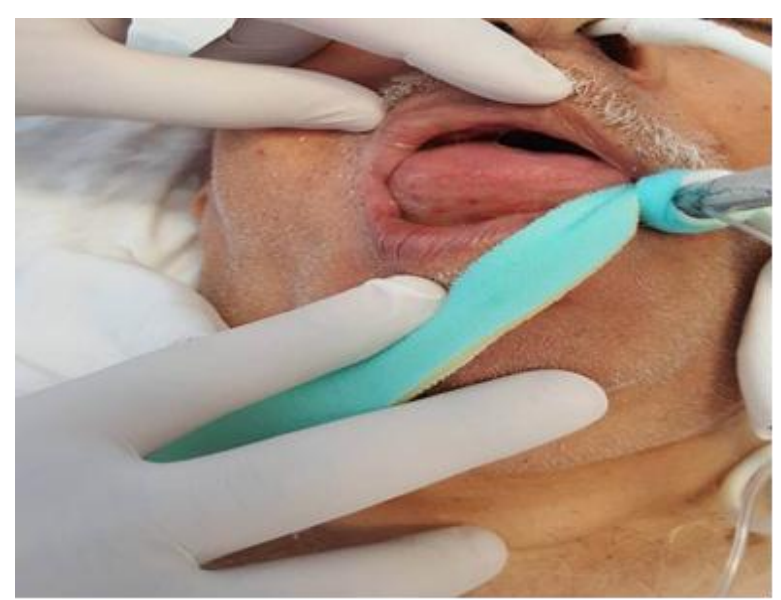

Figure I. Tongue swelling after recombinant tissue plasminogen activator infusion.

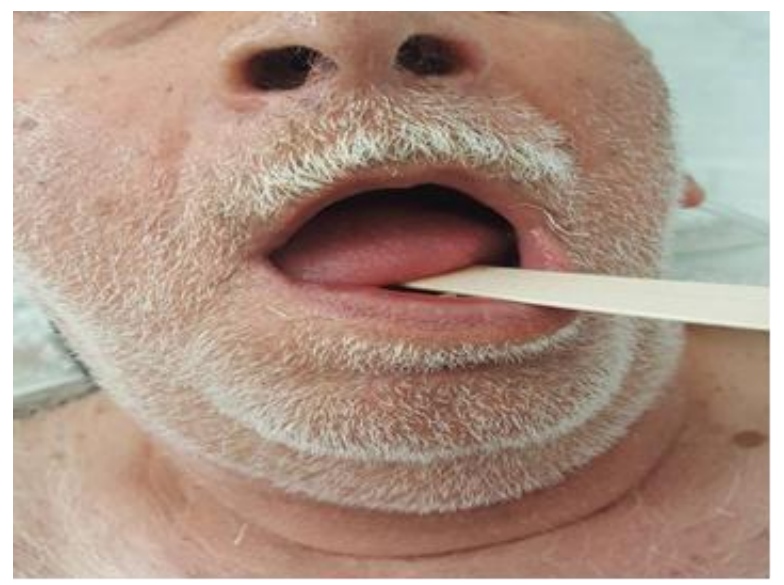

Figure II. Patient's tongue after treatment.

Also, the complement system may be activated by plasmin and the anaphyloxins $\mathrm{C} 3 \mathrm{a}, \mathrm{C} 4 \mathrm{a}$, and $\mathrm{C} 5 \mathrm{a}$, which also cause mast cell degranulation and histamine release, may be produced $(2,8)$. Angioedema may occur as a result of a hereditary deficiency in C1-esterase. We know that patients taking angiotensin-converting enzyme inhibitors (ACEI) are at increased risk of developing this rare complication, but it has also been reported in patients without taking these medications $(5,7)$. Orolingual angioedema following thrombolysis can be bilateral or unilateral $(2,5)$. Yayan found that orolingual angioedema was asymmetrical and ipsilateral to the side of hemiparesis in the majority of their patients who experienced this complication $(7,9)$. There are no guidelines suggesting a specific treatment protocol for the management of orolingual angioedema associated with r-tPA. 
The initial goal of therapy is airway management and patients may require urgent lifesaving procedures such as intubation or tracheotomy. Although it has been recommended to stop r-tPA infusion due to the possibility of extensive airway swelling and an airway disaster in most of the previous reports, termination of IV rtPA infusion might not be required regarding the risks and benefits. Patients who develop angioedema should be treated with histamine antagonists, such as ranitidine and diphenhydramine along with corticosteroids. They should be observed in a neurologic intensive care unit $(9,10)$.

Our case is the first case in our series who developed orolingual angioedema after IV r-tPA administration. A total of 91 patients with acute stroke have received r-tPA in our ICU. In this case, we noticed right hemi orolingual swelling of the patient towards the end of IV r-tPA infusion. The infusion was not stopped due to the timing of angioedema and the absence of respiratory distress during infusion. Furthermore, there was no change in the patient's vital signs and neurological signs. After the infusion was ended, tongue angioedema became prominent with increased respiratory distress and the patient was intubated. Our case was receiving ACEI as in line with most of the patients reported previously. Although the underlying mechanism was not fully understood, the finding of tongue swelling ipsilateral to the lesion side was consistent with the findings of previous reports. The reason why the prognosis was not poor for our patient may be related with the follow-up and treatment of the patient in an ICU and the urgent intubation. The follow up of these patients in ICUs is safe regarding the complications of thrombolysis.

Orolingual angioedema as a complication of $r$ tPA administration in acute stroke patients as well as the most common and dreaded complications such as hemorrhagic transformation should be paid attention. Special care is needed especially if the patient has been consuming ACEI.
As conclusion, orolingual angioedema is a complication of IV r-tPA administration in stroke units and physicians need to be aware of this potential life-threatening complication especially among patients under ACEI treatment. Although the exact mechanism underlying the development of orolingual angioedema has not been elucidated, it may be related with a dysfunction in immune system. Termination of $r$-tPA may not be required if this complication develops towards the end of infusion, under the circumstances of an intensive care unit and in cases who do not have severe respiratory distress.

\section{REFERENCES}

1. De Los Rios F, Kleindorfer DO, Guzik A, et al. Intravenous fibrinolysis eligibility: a survey of stroke clinicians' practice patterns and review of the literature. The Journal of Stroke and Cerebrovascular Diseases 2014; 23(8): 2130-2138.

2. Madden B, Chebl RB. Hemi orolingual angioedema after tPA administration for acute ischemic stroke. The Western Journal of Emergency Mediçine 2015; 16(1): 175-177.

3. Kutluk K, Kaya D, Afsar N et al., Turkish Thrombolysis Study Group. Analyses of the Turkish National Intravenous Thrombolysis Registry. The Journal Stroke of Cerebrovascular Diseases 2016; 25(5): 1041-1047.

4. Motamed MR, Nasiri F, Fereshtehnejad SM, et al. Complicated orolingual angioedema after recombinant tissue plasminogen activator treatment in stroke patients under angiotensin converting enzyme inhibitor: Report of two cases. Iran Journal Neurology 2015; 14(4): 225-227.

5. Fugate JE, Kalimullah EA, Wijdicks EF. Angioedema after tPA: what neurointensivists should know. Neurocritical Care 2012; 16(3): 440-443.

6. Correia AS, Matias G, Calado S, et al. Orolingual angiodema associated with alteplase treatment of acute stroke: a reappraisal. The Journal Stroke of Cerebrovascular Diseases 2015; 24(1): 31-40.

7. Yayan J. Onset of orolingual angioedema after treatment of acute brain Ischemia with Alteplase depends on the site of brain ischemia: a meta-analysis. North American Journal of Medical Sciences 2013; 5(10): 589-593.

8. Molinaro G, Gervais N, Adam A. Biochemical basis of angioedema associated with recombinant tissue plasminogen activator treatment: an in vitro experimental approach. Stroke 2002; 33(6): 1712-1716.

9. Hill MD, Barber PA, Takahashi J, et al. Anaphylactoid reactions and angioedema during alteplase treatment of acute ischemic stroke. Canadian Medical Association Journal 2000; 162(9): 1281-1284.

10. Maertins $M$, Wold $R$, Swider $M$. Angioedema after administration of tPA for ischemic stroke: case report. Air Medical Journal 2011; 30(5): 276-278. 